\title{
Structural variability of Aleppo pine stands in two forests in northeastern Algeria
}

\author{
MALIKA RACHED-KANOUNI ${ }^{1}$, INSAF HANI ${ }^{1}$, RATIBA BOUSBA ${ }^{2}$, AMINA BELDJAZIA ${ }^{3, \bullet}$, \\ HICHEM KHAMMAR ${ }^{1}$ \\ ${ }^{1}$ Laboratory of Functional Ecology and Environment, Department of Nature and Life Sciences, Faculty of Exact Sciences, Nature and Life Sciences, \\ University of "Larbi Ben M'hidi", Oum El Bouaghi. 1st November 1954 Street, Oum el Bouaghi 04000, Algeria \\ ${ }^{2}$ Laboratory of Genetic, Biochemistry and Plant Biotechnology, Department of Biology and Ecology, Faculty of Nature and Life Sciences, University \\ des Frères Mentouri Constantine 1. BP, 325 Ain el Bey Road, Constantine 25017, Algeria. `email: beldjaziaamina@yahoo.fr \\ ${ }^{3}$ Departmnent of Plant Biology and Ecology, Faculty of Nature and Life Sciences, University of Ferhat Abbas Setif 1. El Bez, Setif 19000, Algeria
}

Manuscript received: 26 April 2020. Revision accepted: 30 May 2020.

\begin{abstract}
Rached-Kanouni M, Hani I, Bousba R, Beldjazia A, Khammar H. 2020. Structural variability of Aleppo pine stands in two forests in northeastern Algeria. Biodiversitas 21: 2848-2853. The layout of the stand can be described as the width of the trees, their reciprocal locations, diametric distinction and height. The goal of this study is to recognize changes in the Pinus halepensis spatial and demographic systems in two Beni Oudjana and Chettaba Forests, located in northeast Algeria. An inventory of trees in these forest formations with $P$. halepensis dominance was carried out based on dendrometric parameters such as total height, tree diameter at dbh $\geq$ $5 \mathrm{~cm}$, basal area, total volume, etc., as well as the number of trees in the forest. Tree diameter and height measurements were made on 12 rectangular plots $(20 \mathrm{~m} \times 20 \mathrm{~m})$, located in both forests. The results obtained show that the mean stand density, mean diameter, basal area and total volume are higher in Chettaba Forest, the values attributed to these parameters are respectively $(422$ trees/ha, $27.07 \mathrm{~cm}$, $26,86 \mathrm{~m}^{2}, 251.63 \mathrm{~m}^{3}$ ); while the total height and regeneration rate show significantly higher values in Beni Oudjana Forest (18.97 $\mathrm{m}$, 607 individuals/ha). The structure in diameter and height of the species is bell-shaped to asymmetrically positive with a predominance of small diameter individuals in the Chettaba forest. On the other hand, in the Beni Oudjana Forest, the structure is ' $L$ ' shaped, showing a predominance of very small diameter individuals. These results indicate that the low regeneration rate of $P$. halepensis in the Chettaba Forest is due to anthropogenic pressures that favor the degradation of this forest.
\end{abstract}

Keywords: Demographic structure, Pinus halepensis, regeneration, spatial structure

\section{INTRODUCTION}

In Algeria, the current overly rapid and intense forests damage has induced modification in the vegetation cover, which is essentially made up of three types of plant formations: forest, scrub, and brush. The distribution of these formations depends on environmental factors (relief, orography, geology and geomorphology, climate, etc.) and anthropogenic factors (fires, grazing, etc.) which have significantly influenced on its floristic composition (Halfaoui et al. 2018) and its spatial structure (RachedKanouni et al. 2020).

Among the useful forest species recorded in Algeria, Pinus halepensis has a very wide geographical distribution, covering more than 850.000 hectares (Kherchouche et al. 2011). This species, which is present in all bioclimatic stages from the coast to the Saharan Atlas, finds its optimum growth mainly in semi-arid zones (Goubi et al. 2019). Its plasticity and robust temperament enable it to withstand drought and high temperatures. Thus, its great capacity for survival on poor and very degraded soils permits a very heterogeneous spatial distribution according to bioclimatic stages.

Knowledge of the structural and floristic variability of forests is a basic tool to know the composition and floristic potential of these forests in a given region for their conservation and sustainable management (Krumm et al. 2012).

The spatial structure of tree species appears to be a determining factor in their regeneration, growth, resource use, and mortality processes (Hartmann et al. 2018). Indeed, it helps to detect the local environment of each individual and consequently, through the processes of competition, its capacity to develop and grow, or its probability of exclusion (Whyte et al. 2016).

Stand structure and biodiversity are two important and interrelated ecological and functional features of the forest ecosystem (Pastorella and Paletto 2013). Natural regeneration and tree development affect the composition of the forest and, conversely, these ecological strategies are a response to the spatial context (Seidl et al. 2011). The stand structure has an effect on both aesthetic and recreational values and also on the richness of the species of flora and fauna ( $\mathrm{Su}$ et al. 2012) and it is an essential component in the evaluation of forest ecosystems (Tan et al. 2011).

The spatial distribution of forest species provides information on the mode of seed dispersal, plant evolution, survival, and mortality during their life cycle (Schütz and Zingg 2010). The examination of the species' spatial distribution helps to understand its dynamics, the ecological processes that influence it, the community life of 
the species and determines reproduction, dispersal, resource use, and spacing between individuals (Motz et al 2010; Seidl et al. 2013). The spatial distribution also determines a canopy structure, which plays a key role in the natural regeneration of tree species (Boehm 2011; Manso et al. 2012).

The target of this research is to characterize the spatial distribution of Pinus halepensis populations and to assess its regeneration potential in the two forests located in the north-eastern region of Algeria (Chettaba and Beni Oudjana).

\section{MATERIALS AND METHODS}

\section{Study area}

The study area consists of the Pinus halepensisdominant forest formations of the north-eastern zone of Algeria. They are located precisely in the forests of Chettaba (Constantine) and Beni Oudjana (Khenchela) (map 1). The Chettaba forest, with an estimated area of 2398 ha, is located between the coordinates (X1: $36^{\circ} 18^{\prime}$, X2: $36^{\circ} 21^{\prime}$ ) North latitude and (Y1: $6^{\circ} 26^{\prime}$, Y2: $6^{\circ} 30^{\prime}$ ) East longitude. Its climate changes from semi-arid to subhumid. Medium annual precipitation is estimated at between 670 and $800 \mathrm{~mm} /$ year and the average annual temperature in the study area is $18^{\circ} \mathrm{C}$. The brown calcareous modal soils are generally poor in organic matter.

The Beni Oudjana Forest area is estimated at 14147 ha. It is characterized by a semi-arid climate. Rainfall is generally low and shows great inter-month variability (382$451 \mathrm{~mm} /$ year). Average annual temperatures are 13.6 to $14.9{ }^{\circ} \mathrm{C}$ respectively. The substratum is of the marly and marly-limestone type for the pine forest.

The dominant forest formations are holm oak (Quercus ilex L.) and Aleppo pine (Pinus halepensis Mill). in both forests.

\section{Methods \\ Data collection}

The goal of data collection was to assess the structural and demographic characteristics of Pinus halepensis stands during summer 2019. The dendrometric parameters of two forests have been considered by establishing 12 permanent plots (6 in each forest), square $(20 \mathrm{~m} \times 20 \mathrm{~m})$ in the stands considered most representatives of two forests. Within these plots, all individuals were counted. For each tree, the traditional diameter at breast height (DBH, i.e. $1.30 \mathrm{~m}$ from the ground) and total height were measured by Blume Leiss. Regeneration was obtained by simple counting (Šižková et al. 2011).
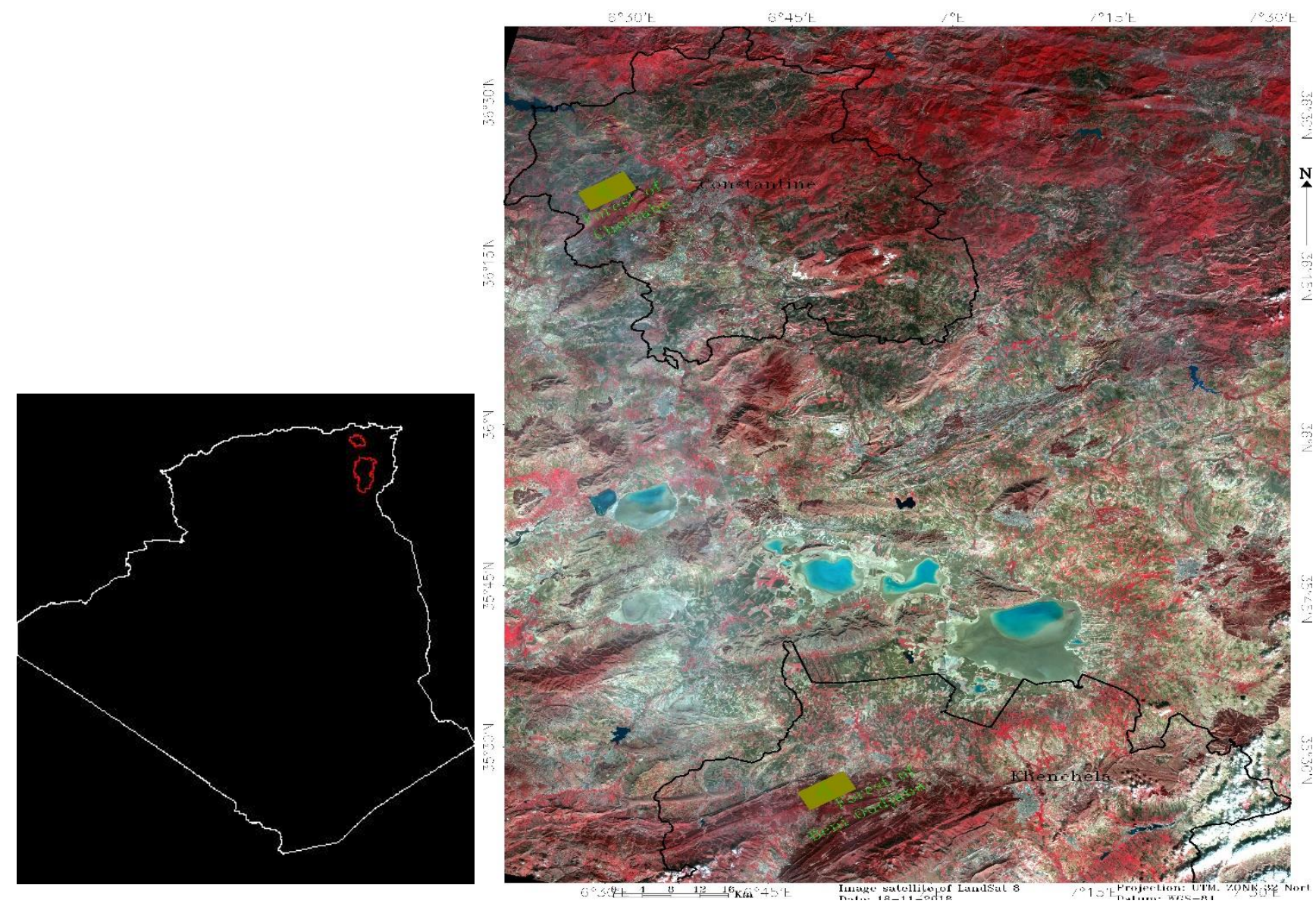

Map 1. The map of study area over pseudo infrared color composition obtained from Landsat 8 satellite processed with ENVI 5.1 software 


\section{Data analysis}

The structural parameters used to characterize Pinus halepensis stands in both forests are density, mean diameter, basal area, mean total height, and total volume. The density of a woody stand expresses the total number of trees per unit area (hectare). The basal area (in $\mathrm{m}^{2} / \mathrm{ha}$ ) is calculated according to the relationship: $\mid G=\Pi D^{2} / 4$ with $\mathrm{G}$ in $\mathrm{m}^{2} / \mathrm{ha}$ and $\mathrm{D}$ expressing the diameter at breast height (Adjonou 2010). Regeneration density is expressed as a percentage for the two forests considered (Keenan et al. 2015). An Analysis of Variance Analysis (ANOVA) test is carried out on structural parameters using MINITAB version 18 software to compare Aleppo pine populations between the two forests.

\section{Demographic structure}

Starting from a $5 \mathrm{~cm}$ threshold, diameter classes with $5 \mathrm{~cm}$ amplitude have been established. Size classes have been established from a threshold of $2 \mathrm{~m}$. These classes were used to create histograms of the distribution of diameter and height classes. A fit test to the theoretical Weibull distribution (Habou et al. 2015; Hamidou et al. 2017) was performed using Minitab 18 software. The three-parameter Weibull theoretical distribution (of position a, scale $b$ and shape $c$ ) was used to characterize stand structure, due to its flexibility and the wide variability of distribution shapes it produces. The parameter corresponded to the threshold value, i.e. the smallest diameter (or height) value used to elaborate the histograms. Parameter $\mathrm{b}$ is dependent on the central value of the distribution of diameter and height classes. Finally, parameter $\mathrm{c}$ is linked to the observed structure and, depending on its value, leads the Weibull distribution to take several forms. Its probability density function $\mathrm{f}(\mathrm{x})$ has the following form (Johnson and Kotz 1970):

$$
f(x)=\frac{c}{h}(x-a / b)^{c-1} \quad \exp \left\lceil-\left(\frac{x-a}{h}\right)^{c}\right\rceil
$$

Where $\mathrm{x}$ is the diameter of the trees, $\mathrm{a}$ is the position parameter, $\mathrm{b}$ is the scale or size parameter, and $\mathrm{c}$ is the shape parameter related to the observed structure. The distribution can take several forms depending on the value of the shape parameter (c). A value of $\mathrm{c}<1$, an inverted $\mathrm{J}$ distribution, is characteristic of multispecies or unevenaged stands, while a value of c> 3.6 is characteristic of stands with a predominance of older individuals. Furthermore, if $1<\mathrm{c}<3.6$, this indicates stands with a predominance of young or small-diameter individuals.

To verify the significance of the adjustment under the null hypothesis of equality between the observed frequency of a diameter (respective height) class under consideration and the theoretical frequency expected according to the Weibull function (Agresti 2010; Pontius and Hallett 2014), a log-linear analysis, an iterative method of analysis of the variance of the logarithm of the class density, was performed.

\section{RESULTS AND DISCUSSION}

\section{Analysis of dendrometric parameters}

Stand structure is usually described by density, size distributions, and horizontal and vertical tree distribution patterns; however, age composition might also have a strong influence on stand structure and dynamics (Gadow et al. 2012; Garet et al. 2012; Bielak et al. 2015).

Statistical analysis of $P$. halepensis stands in the two forests reveals a significant difference in dendrometric parameters (Tables 1 and 2). The mean tree density in Beni Oudjana Forest is 207 stems/ha for a basal area of $2.92 \mathrm{~m}^{2} /$ ha while that of Chettaba Forest is higher and is $442 \mathrm{stems} / \mathrm{ha}$ for a basal area of $26.86 \mathrm{~m}^{2} / \mathrm{ha}$. The total volume is also higher in the Chettaba forest than that of Beni Oudjana with values of 251.63 and $58.03 \mathrm{~m}^{3} / \mathrm{ha}$ respectively. Average density, basal area, and total volume seem higher in wetter areas (Rabiou et al. 2015). The distribution of $P$. halepensis would thus be strongly linked to the rainfall regime.

Table 1. Density and regeneration rate of Aleppo pine stands.

\begin{tabular}{lcc}
\hline & Beni Oudjana & Chettaba \\
\hline Average density & $207 \pm 105$ & $442 \pm 158$ \\
Moyenne & individual/ha & individual $/ \mathrm{ha}$ \\
Regeneration rate & $607 \%$ & $174 \%$ \\
\hline
\end{tabular}

Table 2. Principal dendrometric characteristics of Aleppo pine in both habitats

\begin{tabular}{lccccc}
\hline \multirow{2}{*}{ Parameters } & \multicolumn{2}{c}{ Beni Oudjana } & \multicolumn{2}{c}{ Chettaba } & Value p \\
\cline { 2 - 5 } & \multicolumn{1}{c}{ Average } & Variance Coefficient & Average & Variance Coefficient & \\
\hline Diameter $(\mathrm{cm})$ & $12.12 \pm 4.94^{\mathrm{b}}$ & 40.76 & $27.03 \pm 5.36^{\mathrm{a}}$ & 19.83 & 0.0000 \\
Height $(\mathrm{m})$ & $18.97 \pm 8.01^{\mathrm{a}}$ & 42.17 & $9.410 \pm 1.24^{\mathrm{b}}$ & 13.19 & 0.0005 \\
Basal area $\left(\mathrm{m}^{2} / \mathrm{ha}\right)$ & $2.92 \pm 1.22^{\mathrm{b}}$ & 41.78 & $26.86 \pm 5.57^{\mathrm{a}}$ & 20.72 & 0.0010 \\
Total volume $\left(\mathrm{m}^{3} / \mathrm{ha}\right)$ & $58.03 \pm 24.02^{\mathrm{a}}$ & 41.39 & $251.63 \pm 60.96^{\mathrm{a}}$ & 24.23 & 0.2000 \\
\hline
\end{tabular}


The mean total height of trees is estimated at $18.97 \mathrm{~m}$ in the Beni Oudjana Forest and $9.4 \pm 1.5 \mathrm{~m}$ in the Chettaba Forest. Conversely, to the height results, the average diameter of the trees is equal to $12.12 \mathrm{~m}$ for the Beni Oudjana Forest and $27.03 \mathrm{~m}$ for the Chettaba Forest (Table 2). Variance tests carried out on the values obtained for these dendrometric parameters showed a significant difference between the two forests $(\mathrm{F}=3.60$; $\mathrm{p}<0.05$ for total height and $\mathrm{F}=1.37$; $<<0.2$ for mean diameter). The traditional approach to presenting the vertical distribution pattern of tree species is to use a hand drawing of the vertical stand profile or a photograph, as has frequently been done in the case of primeval forests (Rached-Kanouni et al. 2020). However, a more advanced and complete description of the vertical structure requires the spatial positions of trees to be specified along with their size and species. Tree height is a particularly important size variable that can be used to describe the vertical structure of the stand (Alberdi et al. 2013). If all tree heights are known or can be reliably estimated for each species, frequency histograms can show the distribution of stem density, basal area, etc., for each tree species separately within defined height classes. Descriptive statistics of these height distributions might be used in the stand-level analysis in the same way as diameter distributions (Adame et al. 2014). Similarly, mean height and standard deviation or variation coefficient of tree height can be used as a straightforward index to assess vertical structure (Barbeito et al. 2014). However, it is important to take into account that the standard deviation might be underestimated when some tree heights are estimated instead of being measured (Barbati et al. 2012).

Density is an ecological term to quantify the concentration of a species in an ecosystem per unit area. Stand density is a concept used in forestry to define the covering. Density is linked to the occupation of a location, showing how much services the trees use for a site's natural capital (Belote et al. 2011), e.g. in terms of growing area, and therefore to tree volume, biomass, growth, and survival.

In our case, the average density, basal area, and total volume are higher in the Chettaba forest with a rainfall of 670 to $800 \mathrm{~mm} /$ year; while that of Beni Oudjana is 382 to $451 \mathrm{~mm} /$ year. The lower average diameter recorded in the Beni Oudjana Forest is explained by the high frequency of small diameter. On the other hand, the high mean diameter observed in the Chettaba Forest is due to the predominance of older individuals (Kolström et al. 2011; Rached-Kanouni and Kara 2019).

Regeneration constitutes the future potential of the forest. The presence of young forest species seedlings would imply the existence of reproductively active adults. In our case, the direct observation of adult individuals shows that they are in very small numbers in the Beni Oudjana Forest compared to those of Chettaba. Small diameter individuals are less represented due to a recruitment deficit. On another note, the dominance of large-diameter individuals could be linked to climatic factors combined with anthropogenic factors (fire, grazing, etc.) that constitute the main obstacles to regeneration (Rached-Kanouni and Kara. 2019).

\section{Diameter structure of $\boldsymbol{P}$. halepensis stands}

The distribution of trees in diameter classes shows a different situation for the two environments. In the Beni Oudjana Forest, the diameter structure of the $P$. halepensis stand shows an inverted J-shape with the shape parameter c taking a value less than 1 (Figure 1). This structure is therefore regressive and characteristic of a natural stand with high regeneration potential (Kemadjou, 2011).

The diameter distribution of $P$. halepensis trees in the Chettaba Forest shows a bell-shaped structure with a straight asymmetry. The shape parameter $\mathrm{c}$ is equal to 3.3. Trees with diameters between $20 \mathrm{~cm}$ and $30 \mathrm{~cm}$ are the most numerous per hectare (Figure 2). Individuals of small diameter are mostly absent. The log-linear analysis shows that all these structures fit the different theoretical Weibull distributions with $\mathrm{p}<0.05$.

The diameter structure of natural stands of $P$. halepensis reveals high overall representativeness of largediameter old-growth individuals in the Chettaba forest. This exception can be explained by the ecological and climatic characteristics of this zone, which appears to be the wettest compared to the Beni Oudjana forest. Factors such as grazing or repeated fires are likely to hamper the survival of young seedlings and make natural regeneration very weak or even nil in the Chettaba forest than in the Beni Oudjana forest. The pre-urban chettaba forest is subject to enormous human actions. (Lemouissi et al. 2014; Megrerouche et al. 2015). In this case, the regeneration of the species requires urgent silvicultural work to understand what explains this low regeneration potential (Rached and Kara 2019). Potential regeneration is low. Human actions greatly reduce the chances of regeneration. According to Pretzsch and al. (2015a), repeated wildfires combined with grazing would have a more negative influence on tree regeneration (recruitment) than when each of these anthropogenic pressures is considered separately (Natta 2011a). Beyond anthropogenic pressure (fire, waste, grazing, etc.), climatic factors, therefore, contribute to the degradation of the character stands in this area (RachedKanouni et al. 2020).

\section{Height structure}

The graphs in figures 3 and 4 show different distributions of total height between the two forests. The value of the Weibull c-form parameter of the height structure of $P$. halepensis in the Beni Oudjana Forest is less than 1, indicating an ' $L$ ' distribution predominantly of small diameter individuals reflecting a regular population dynamics of $P$. halepensis in the Beni Oudjana Forest (Figure 3). In the Chettaba Forest, the dominant high class is between 8 and $12 \mathrm{~m}$ indicating a bell shape with a positive right asymmetrical shape, characteristic of monospecific stands (Figure 4). The value of the shape parameter $\mathrm{c}$ of the Weibull distribution is between 1 and $3.6(c=2.78)$ (Glèlè Kakaï et al. 2016). The log-linear analysis carried out for each of these structures indicates a good fit of the data to the Weibull distribution for the different groups and the overall stand (prob. >0.05). 


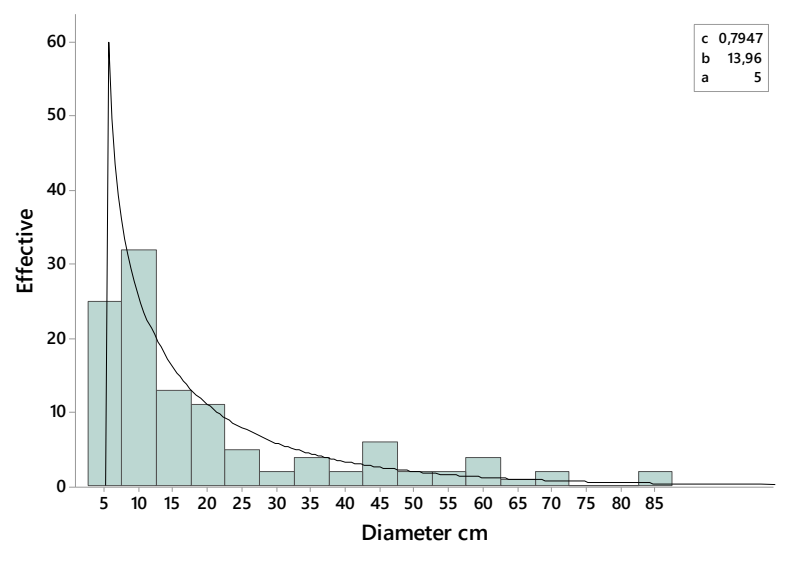

Figure 1. Diameter class in Beni Oudjana forest.

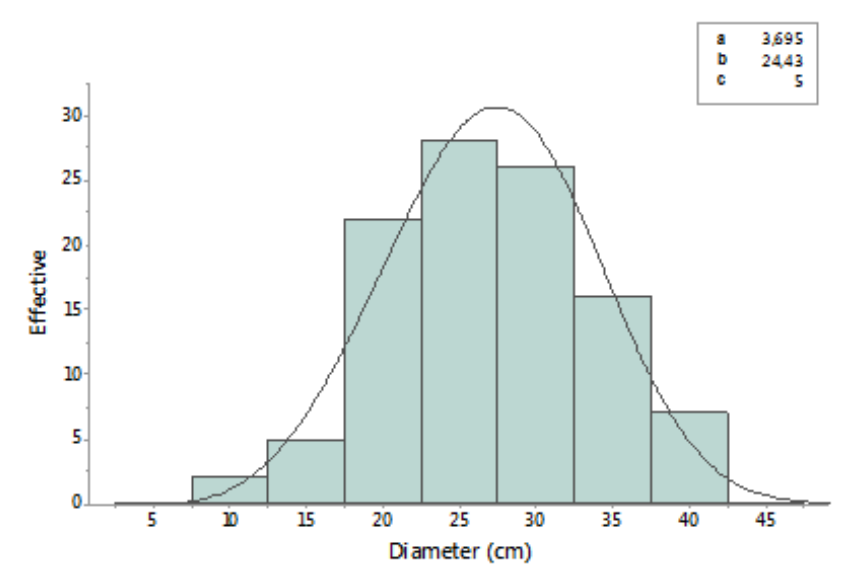

Figure 2. Diameter class in Chettaba forest

The demographic structure of trees in height classes reveals a predominance of medium-sized trees ( 2 to $4 \mathrm{~m}$ ) for the Beni Oudjana forest. These structures show a positive evolution of $P$. halepensis stands in this massif where stand renewal is ensured (Svoboda and al. 2012; Notaro and Paletto 2012). The absence of young individuals, particularly in the Chettaba Forest, is due to the anthropic action exerted by the riparian population on the Aleppo pine stand (Rached-Kanouni and Kara 2019).

To conclude, this study is an inventory of two forests (Chettaba and Beni Oudjana) located in northeastern Algeria to characterize the structural variability of the dominant species (Pinus halepensis) in these two forests. The results obtained show that the Chettaba Forest is characterized by a stand dominated by large-diameter individuals, with young or small-diameter individuals being less dominant, which reflects a problem of regeneration of the species. Anthropic factors are the primary cause of the degradation of this forest. The species regenerates best in the Beni Oudjana Forest (the least watered area) where it finds its full development; this is explained by the weak anthropic action in this area. Finally, the results of the present research in two forests are also useful for any scientist who wishes to use them to get an

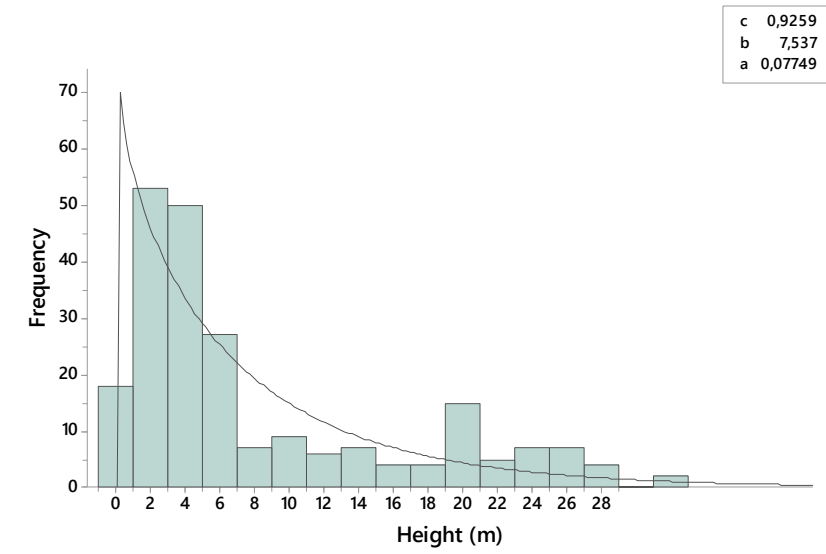

Figure 3. Height class in Beni Oudjana forest

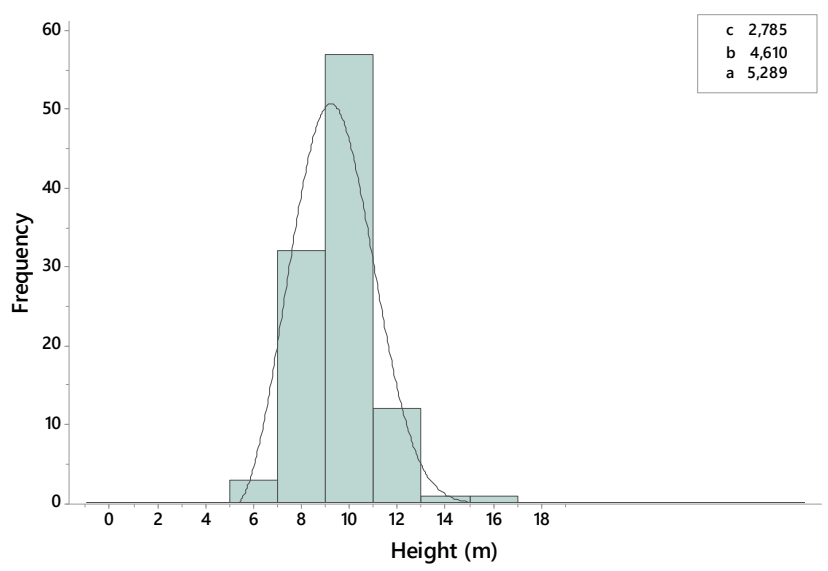

Figure 4. Height class in Beni Oudjana forest

idea of the variability of the structure of Aleppo pine stands in the Chettaba and Beni Oudjana forests in eastern Algeria so that a rational management plan and sustainable of the region's forest resources can be proposed

\section{REFERENCES}

Adame P, Brandeis TJ, Uriarte M. 2014. Diameter growth performance of tree functional groups in Puerto Rican secondary tropical forests. For Syst 23 (1): 52-63.

Adjonou K, Ali N, Kokutse AD, Novigno SK. 2010. Etude de la dynamique des peuplements naturels de Pterocarpus ericaceus Poir. (Fabaceae) surexploités au Togo. Bois et Forêts des Tropiques 306 (1): 45-55.

Agresti A. 2010. Analysis of Ordinal Categorical Data. 2 $2^{\text {nd }}$ edition. New York, USA, Wiley 424p.

Alberdi I, Cañellas I, Hernández L, Conde's S. 2013. A new method for the identification of old-growth trees in National Forest Inventories: application to Pinus halepensis Mill stands in Spain. Ann For Sci 70: 277-285.

Barbati A, Salvati R, Ferrari B, Di Santo D, Quatrini A, Portoghesi L, Travaglini D, Iovino F, Nocentini S. 2012. Assessing and promoting old-growthness of forest stands: lessons from research in Italy. Plant Biosyst 146 (1): 167-174.

Barbeito I, Collet C, Ningre F. 2014. Crown responses to neighbour density and species identity in a young mixed deciduous stand. Trees 28: 1751-1765. 
Belote RT, Prisley S, Jones RH, Fitzpatrick M, De Beurs K. 2011. Forest productivity and tree diversity relationships depend on ecological context within mid-Atlantic and Appalachian forests (USA). For Ecol Manag 261 (7): 1315-1324

Bielak K, Dudzin'ska M, Pretzsch H. 2015. Volume growth of mixedspecies versus pure stands: results from selected long-term experimental plots in Central Europe. Sylwan 159 (1): 22-35.

Boehm DA. 2011. Forestry: Research, Ecology, and Policies. Nova Science Publishers, New York.

Gadow KV, Zhang CY, Wehenkel C, Pommerening A, Corral-Rivas J, Korol M, Myklush S, Hui GY, Kiviste A, Zhao XH. 2012. Forest structure and diversity. In: Pukkala T, Gadow Kv (eds) Continuous Cover Forestry. Book Series Managing Forest Ecosystems 23. Springer, Berlin.

Garet J, Raulier F, Pothier D, Cumming SG. 2012. Forest age class structures as indicators of sustainability in boreal forest: are we measuring them correctly? Ecol Indicat 23: 202-210.

Glèlè Kakaï R, Bonou W, Lykke AM. 2016. Approche méthodologique de construction et d'interprétation des structures en diamètre des arbres. Annales des Sciences Agronomiques 20-spécial Projet Undesert-UE: 95-105.

Goubi M, Bentouati A, Kherchouche D, Sghaier T. 2019. Tarifs et tables de cubage d'arbres individuels du pin d'Alep, Pinus halepensis Mill., dans l'Aurès algérien. Bois et Forêts des Tropiques 339: 45-59. [France]

Habou R, Abdoulaye D, Babou A, Kossi N, Kossi A, Adzo D, Raoufou R, Kouami K, Ali M, Mahamane S. 2015. Structure des peuplements naturels de Pterocarpus erinaceus Poir. dans le domaine soudanien, au Niger et au Burkina Faso. Bois et forêts des tropiques 325 (3): 7183. [France]

Halfaoui F, Touahria S, Bouchenak F, Chaouia C. 2018. Conséquences de la dégradation des formations végétales de la région de Tamezguida, wilaya de Médéa. Revue Agrobiologi 8 (2): 1165-1179. [France]

Hamidou A, Habou R, Abdoulaye D, Boubé M, Ali M, Ronald B. 2017. Structure démographique et répartition spatiale des populations de Sclerocarya birrea (A. Rich.) Hochst du secteur sahélien du Niger. Bois et forêts des tropiques, 333 (3): 55-65. [France]

Hartmann H, Moura CF, Anderegg WRL, Ruehr NK, Salmon Y, Allen CD, Arndt SK, Breshears DD, Davi H, Galbraith D, Ruthrof KX Wunder J, Adams HD, Bloemen J, Cailleret M, Cobb R, Gessler A, GramsTEE, Jansen S, Kautz M, Lloret F, O'Brien M. 2018. Research frontiers for improving our understanding of drought-induced tree and forest mortality. New Phytol 218: 15-28.

Johnson NL Kotz S. 1970. Distributions in Statistics: Continuous Univariate Distributions. John Wiley \& Sons, New York, USA.

Keenan RJ, Reams GA, Achard F, De Freitas JV, Grainger A, Lindquis E. 2015. Dynamics of global forest area: results from the FAO Global Forest Resources Assessment 2015. For Ecol Manag 352: 9-20.

Kherchouche D, Bentouati A, Kaabeche M. 2011. Croissance et écologie du pin d'Alep (Pinus halepensis Mill.) dans le massif des Beni-Imloul (Aurès, Algérie). Sécheresse 22: 43-48. [France]

Kolström M, Lindner M, Vile'n T, Maroschek M, Seidl R, Lexer MJ, Netherer S, Kremer A, Delzon S, Barbati A, Marchetti M, Corona P. 2011. Reviewing the science and implementation of climate change adaptation measures in European forestry. Forests 2: 961-982.

Krumm F, Kulakowski D, Risch AC, Spiecker H, Bebi P. 2012. Stem exclusion and mortality in unmanaged subalpine forests of the Swiss Alps. Eur J For Res 131: 1571-1583.

Lemouissi S, Rached-Kanouni M, Hadef A, Amine Khoja M, Alatou D. 2014. Adaptation of Holm oak (Quercus ilex L.) to seasonal climate variations. Intl J Manag Sci Bus Res 3 (5): 30-35.

Manso R, Pardos M, Keyes C, Calama R. 2012. Modelling the spatiotemporal pattern of primary dispersal in stone pine (Pinus pinea $\mathrm{L}$.) stands in the Northern Plateau (Spain). Ecol Model 226: 11-21.
Megrerouche R, Rached-Kanouni M, Amine Khodja AEM, Alatou D. 2015. Susceptibility to Fire (Case the Forest of Chettabah, Algeria). Intl J Manag Sci Bus Res 4 (4): 8-13.

Motz K, Sterba H, Pommerening A. 2010. Sampling measures of tree diversity. For Ecol Manag 260: 1985-1996.

Natta AK, Yédomonhan H, Zoumarou-Wallis N, Houndéhin J, Ewédjè EBK, Glèlè Kakaï RL. 2011a. Typologie et structure des populations naturelles de Pentadesma butyracea dans la zone soudano-guinéenne du Bénin. Annales des Sci Agronomiques 15: 217-243. [France]

Notaro S., Paletto A., (2012). The economic valuation of natural hazards in mountain forests: An approach based on the replacement cost method. J For Econ 18: 318-328.

Pastorella F, Paletto A. 2013. Stand structure indices as tools to support forest management: an application in Trentino forests (Italy). J For Sci 59 (4): 159-168

Pontius J, Hallett R. 2014. Comprehensive Methods for Earlier Detection and Monitoring of Forest Decline. Forest Science 60 (6): 1156-1163.

Pretzsch H, Biber P, von Gadow K. 2015a. Ernst Assmann: a German pioneer in forest production ecology and quantitative silviculture. Eur J For Res 134 (3): 391-402

Quezel P, 1986a. Les pins du groupe «halepensis». Ecologie, végétation, écophysiologie Options Méditerranéennes. Série Etude CIHEAM 86/1 11-24. [France]

Rabiou H, Diouf A, Bationo BA, Segla KN, Adjonou K, Kokutse AD, Radji R, Kokou K, Mahamane A, Saadou M. 2015. Structure des peuplements naturels de Pterocarpus erinaceus Poir. dans le domaine soudanien, au Niger et au Burkina Faso. Bois et forêts des tropiques 325 (3): 71-83. [France]

Rached-Kanouni M, Kara K, Khammar H, Ababsa L. 2020. Floristic diversity and demographic structure of the Sidi R'Ghies forest, northeastern of Algeria. Biodiversitas 21: 875-881.

Rached-Kanouni M, Kara K. 2019. Structure indices of Aleppo pine in chettaba forest (Algeria). Proceeding International Conference on Earth and GeoSciences, 9-12 December, Palais Niederösterreich, Vienna, Austria 395-400.

Schütz JP, Zingg A (2010) Improving estimations of maximal stand density by combining Reineke's size-density rule and the yield level, using the example of spruce (Picea abies (L) Karst) and European Beech (Fagus sylvatica L). Ann For Sci 67: 507.

Seidel D, Leuschner C, Scherber C, Beyer F, Wommelsdorf T, Cashman MJ, Fehrmann L. 2013. The relationship between tree species richness, canopy space exploration and productivity in a temperate broad-leaf mixed forest. For Ecol Manag 310: 366-374.

Seidl R, Schelhaas MJ, Lexer MJ. 2011. Unraveling the drivers of intensifying forest disturbance regimes in Europe. Global Change Biol 17: 2842-2852

Šižková P, Svoboda M, Křenovâ Z. 2011. Natural regeneration of acidophilous spruce mountain forests in non-intervention management areas of Šumava National Park-the first results of the Biomonitoring project. Silva Gabreta 17: 19-35.

Su D, Yu D, Zhou L, Xie X, Liu Z, Dai L. 2012. Differences in the structure, species composition and diversity of primary and harvested forests on Changbai Mountain, Northeast China. J For Sci 56: 285293.

Svoboda M, Janda P, Nagel TA, Fraver S, Rejzek J, Bace R. 2012. Disturbance history of an old-growth sub-alpine Picea abies stands in the Bohemian Forest, Czech Republic. J Veg Sci 23: 86-97.

Tan SA, Salim R, Hamzah KA, Mamat MR. 2011. Correlation of forest canopy and forest ecological structures in a logged-over forest. Malaysian Forester 74: 31-36

Whyte G, Howard K, Hardy GESJ, Burgess TI. 2016. The tree decline recovery seesaw; a conceptual model of the decline and recovery of drought-stressed plantation trees. For Ecol Manag 370: 102-113. 